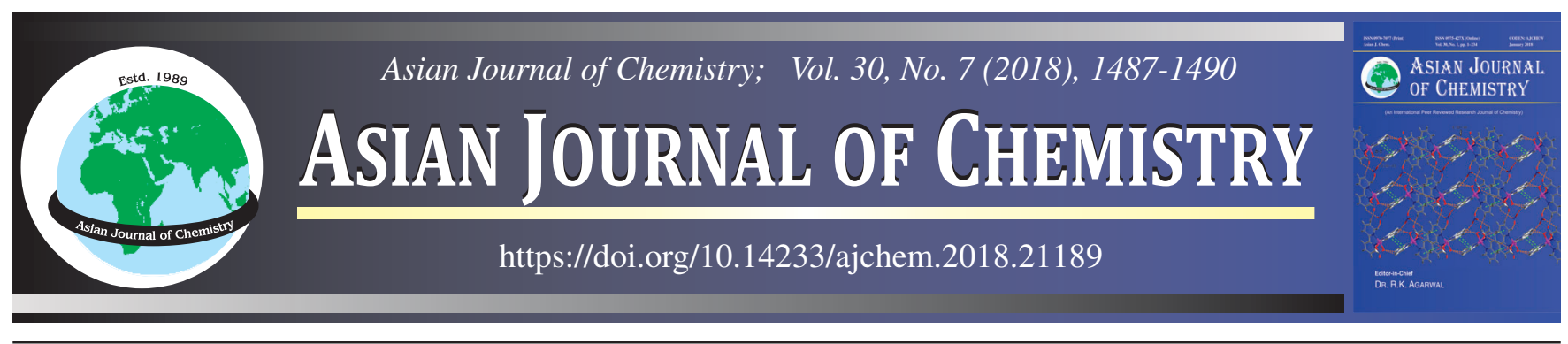

\title{
Distribution of Cadmium in Seawater, Sediment and Soft Tissue of Bivalve in Van Don Coastal in Quang Ninh, Vietnam
}

\section{Luu Ngoc Thien ${ }^{1, *}$ and Nguyen Cong Thanh ${ }^{1,2}$}

${ }^{1}$ Center for Marine Environmental Research and Monitoring, Research Institute for Marine Fisheries, No. 224 Le Lai street, Ngo Quyen district, Hai Phong city, Vietnam

${ }^{2}$ Institute of Environmental Technology, Vietnam Academy of Science and Technology, 18 Hoang Quoc Viet Road, Cau Giay District, Hanoi, Vietnam

*Corresponding author: E-mail: lnthien@ rimf.org.vn

Received: 18 December 2017;

Accepted: 9 February 2018;

Published online: 31 May 2018;

AJC-18918

Level of cadmium were determined in coastal water, sediments and soft tissues molluscs hakf-crenate ark (Anadara subcrenata), noble scallop (Mimachlamys nobilis) and undulating venus (Paphia undulata), from two stations in bivalves harvesting areas in Van Don, Quang Ninh province. In this study, cadmium concentration in seawater ranged between 0.22 to $1 \mu \mathrm{g} . \mathrm{L}^{-1}$ while that concentration in sediment were from 0.59 to $1.55 \mathrm{mg} \mathrm{kg}^{-1}$. Accumulate cadmium in hakf-crenate ark (Anadara subcrenata), noble scallop (Mimachlamys nobilis) and undulating venus (Paphia undulata) were from 0.81 to $1.48 \mathrm{mg} \mathrm{kg}^{-1}$; from 0.35 to $2.23 \mathrm{mg} \mathrm{kg}^{-1}$; from 0.25 to $0.81 \mathrm{mg} \mathrm{kg}^{-1}$, | respectively. The result also show that the cadmium in seawater in rain season were higher dry season while reversibility trend in sediment. The cadmium fraction in sediment in this area were contributed according to follow: residual component (F5) $>$ Mn, Fe oxyhydroxide $(\mathrm{F} 3)>$ organic matter-bound $(\mathrm{F} 4)>$ acid soluble $(\mathrm{F} 2)>$ ion-changeable $(\mathrm{F} 1)$. Cadmium levels in tissue were in the order of stomach $>$ mantle $>$ gill $>$ foot. Beside, cadmium component in adductor muscle of noble scallop were least. The results of study could serve as a baseline for future assessments of anthropogenic effect in this coastal and food safety problems.

Keywords: Cadmium, Accumulation, Sediment, Bivalves.

\section{INTRODUCTION}

Van Don coastal in Bai Tu Long bay (recessed area in Gulf of Tonkin) where located important economic gateway for merchant ships. This place were the first commercial port in Vietnam to transport and exchange other places in Asia and the world. At present, Van Don district have become big economic center of Quang Ninh province and has one of the best special economic zone in Vietnam. Van Don coastal were also where to many concentrated commonly seafood species and high economic values such as: oyster, shrimp, squid, pearl oyster, swimming crap, hand clam, blood cockle, scallop, abalona, octopus, etc. However, the humans activities including shipping, industry, building, dredging etc. contributed to increase marine ecosystems pollutions mainly heavy metal ions that known to be not nutrient values metals and high toxic. Therefore, the heavy metal monitoring in seawater, sediment and organism were necessary to assess aquatic environment in this area. On the other hand, data for heavy metals concentration with high toxicity include $\mathrm{Cd}, \mathrm{Pb}, \mathrm{Hg}$ and their speciations from the coastal area were scare and spare. This study, for the first time, the concentration of cadmium in seawater, sediment and its accumulation in the tissue of scallop (Mimachlamys nobilis), undulating venus (Paphia undulata) and half-crenate ark (Anadara subcrenata) in Van Don coastal were investigated. The results of study could serve as a baseline for future assessments of anthropogenic effect in this coastal.

\section{EXPERIMENTAL}

All reagents used were of analytical grade pure. Deionized water was used for the preparation of reagents and standards. Commercial standard solutions (1000 $\mathrm{mg} \mathrm{L}^{-1}$ ) of cadmium(II) were used (Merck, USA). The working standard solutions were prepared by diluting an appropriate aliquot of the standard stock solutions. All the glass ware was treated with $\mathrm{H}_{2} \mathrm{SO}_{4}$ and $\mathrm{K}_{2} \mathrm{Cr}_{2} \mathrm{O}_{7}$ then immersed into $15 \%$ (v/v) $\mathrm{HNO}_{3}$ for $24 \mathrm{~h}$ and finally rinsed three times with deionized water before use.

Three kinds of bivalves include scallop (Mimachlamys nobilis), undulating venus (Paphia undulata) and half-crenate ark (Anadara subcrenata) which are commonly consumed by the habitant of Van Don coastal. Samples of water, sediment (about 5 to $10 \mathrm{~cm}$ thickness of the surface sediment) and bivalves were collected at two stations in bivalves harvesting 
TABLE-1

FIVE-STEP TESSIER (1979) SEQUENTIAL EXTRACTION PROCEDURE FOR THE SPECIATION OF HEAVY METAL [Ref. 4]

\begin{tabular}{|c|c|c|}
\hline Fraction & Reaction chemical & Condition \\
\hline F1: Exchangeable & 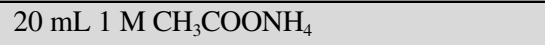 & Stirring about $1 \mathrm{~h}$ at room temperature. \\
\hline F2: Bound to carbonate & $\begin{array}{l}40 \mathrm{~mL} 1 \mathrm{M} \mathrm{CH}_{3} \mathrm{COONH}_{4} \text { (Adjust to } \mathrm{pH} 5 \text { by } \\
\mathrm{CH}_{3} \mathrm{COOH} \text { ) }\end{array}$ & $\begin{array}{l}\text { The residue from }(\mathrm{F} 1) \text { were stirred about } 5 \mathrm{~h} \text { at room } \\
\text { temperature }\end{array}$ \\
\hline F3: Bound to iron-manganese oxide & $\begin{array}{l}40 \mathrm{~mL} 0.02 \mathrm{M} \mathrm{NH}_{2} \mathrm{OH} . \mathrm{HCl} \text { contain } \\
\mathrm{CH}_{3} \mathrm{COOH} 25 \%\end{array}$ & The residue from $(\mathrm{F} 2)$ were stirred about $5 \mathrm{~h}$ at $95-100{ }^{\circ} \mathrm{C}$ \\
\hline F4: Bound to organic compounds & $20 \mathrm{~mL} 3.2 \mathrm{M} \mathrm{CH}_{3} \mathrm{COONH}_{4}$ in $\mathrm{HNO}_{3} 20 \%$ & $\begin{array}{l}\text { The residue from }(\mathrm{F} 3) \text { were stirred about } 0.5 \mathrm{~h} \text { at room } \\
\text { temperature }\end{array}$ \\
\hline F5: Residual & Mix of 5: $1 \mathrm{HNO}_{3}$ and $\mathrm{H}_{2} \mathrm{O}_{2}$, respectively & $\begin{array}{l}\text { The residue from }(\mathrm{F} 4) \text { were reacted in Teflon vessels at } \\
100{ }^{\circ} \mathrm{C}\end{array}$ \\
\hline
\end{tabular}

area in Van Don coastal (latitude $20^{\circ} 38^{\prime} 43.2$; longitude $107^{\circ} 25^{\prime} 2.52 \mathrm{E}$ ) and latitude $21^{\circ} 01^{\prime} 21.2 \mathrm{~N}$; longitude $107^{\circ} 25^{\prime} 31.32 \mathrm{E}$ ) from March 2015 to December 2015. Sampling location was detected using GPS localization.

Sample preparation: The sediment samples after collection were dried in the oven at $70{ }^{\circ} \mathrm{C}$ then were sieved with a $2 \mathrm{~mm}$ size sieve to remove large particles and kept in polyethylene until analysis. The bivalve samples were removed inedible parts, washed and stored after collection in plastic bags in freeze. The seawater samples were collected separately in clean polyethylene containers for heavy metal analyses. They were filtered through a $0.45 \mu \mathrm{m}$ membrane filter, little acidified and stored until analyze.

Methods of analysis: Total cadmium in seawater samples were direct measured by differential pulse anodic stripping voltammetry method (DPASV) to quantitative the cadmium concentration used mercury drop electrode [1].

$0.5 \mathrm{~g}$ of dry sediment samples were digested in Teflon vessels for $2 \mathrm{~h}$ with $16 \mathrm{~mL}$ of $65 \% \mathrm{HNO}_{3}$ and $2 \mathrm{~mL} \mathrm{H}_{2} \mathrm{O}_{2}$ at $150{ }^{\circ} \mathrm{C}$ according to method were described by UNEP/IOC/ IAEA [2]. After disgestion, the sample was allowed to cool. Then, eluted was $50 \mathrm{~mL}$ deionizer water (sample solution).

The whole soft tissue of study bivalves and parts of their bodies (stomach, gills, matel, foot and adductor muscle) was dissected to separate the different organs then were digested in concentrated nitric acid (FAO) [3].

The fraction of cadmium in surface sediment were extracted by five-step, Tessier sequential extraction process, including fraction 1 (exchange), fraction 2 (bound to carbonate), fraction 3 (bound to iron-manganese oxide), fraction 4 (bound to organic compounds) and fraction 5 (residual) (Table-1) [4].

Total cadmium and their fraction in sediment, cadmium accumulated in tissue soft of bivalves and their bodies were also determined by anodic stripping voltammetry method used drop mercury electrode.

Statistical analysis: Statistical analysis of data was carried out using SPSS 16.0 version. A one-way analysis of variance (ANOVA) was performed, followed by LSD post comparisons for the source of statistically significant difference. Differences in mean values were accepted as being statistically significant if $\mathrm{p}<0.05$.

\section{RESULTS AND DISCUSSION}

Cadmium in seawater: The variation of cadmium in seawater collected from the two stations of Van Don coastal are summarized in Table-2. Concerning the sites variation, the levels of cadmium varied from 0.22 to $0.98 \mu \mathrm{L}^{-1}$. The rainy season were trend higher than dry season, main cause by the continental disturbance of the study area. The pollutant source may be created from waste discharge in the mining that used acid dissolve process, shiping activities (such as repair, fueling and painting of fish ship) and other of human activities. At the nearest station of mainland (QN1), cadmium in seawater were higher than other station (QN2) (Fig. 1). However, the average value between this stations were not significantly different $(\mathrm{P}$ $<0.05)$. All samples were very much lower than permitted level set by QCVN 10:2015/BTNMT [5] applied for cadmium in seawater. The results of this study were similar values measured by other researchers in South East Coast of India which ranged between 0.1-3.32 $\mu \mathrm{g} \mathrm{L}^{-1}$ [6]. Upon comparison with study result of Hoi et al. [7] showed that the cadmium concentration in seawater in this area were slowly increasing after 20 years (from 0.3 upto $0.5 \mu \mathrm{g} \mathrm{L}^{-1}$ ).

Cadmium in sediment: Table-3 shown the concentration of cadmium in sediment samples collected from the two stations in the bivalves harvesting area in Van Don coastal. Generally, relatively low concentration of $\mathrm{Cd}$ has been found

TABLE-2

CONCENTRATION OF Cd $\left(\mu \mathrm{g} \mathrm{L}{ }^{-1}\right)$ IN SEAWATER SAMPLES COLLECTED FROM VAN DON COASTAL DURING 2015

\begin{tabular}{ccc}
\hline \multirow{2}{*}{ Month } & \multicolumn{2}{c}{ Survey station } \\
\cline { 2 - 3 } & QN1 & QN2 \\
\hline 3 & $0.222 \pm 0.013$ & $0.251 \pm 0.008$ \\
4 & $0.248 \pm 0.006$ & $0.276 \pm 0.006$ \\
5 & $0.527 \pm 0.004$ & $0.384 \pm 0.005$ \\
6 & $0.986 \pm 0.007$ & $0.672 \pm 0.008$ \\
7 & $0.476 \pm 0.005$ & $0.479 \pm 0.009$ \\
8 & $0.711 \pm 0.009$ & $0.377 \pm 0.009$ \\
9 & $0.468 \pm 0.008$ & $0.651 \pm 0.007$ \\
10 & $0.481 \pm 0.005$ & $0.553 \pm 0.010$ \\
11 & $0.532 \pm 0.006$ & $0.723 \pm 0.009$ \\
12 & $0.527 \pm 0.005$ & $0.496 \pm 0.008$ \\
Average & 0.520 & 0.486 \\
SD & 0.222 & 0.164 \\
\hline
\end{tabular}

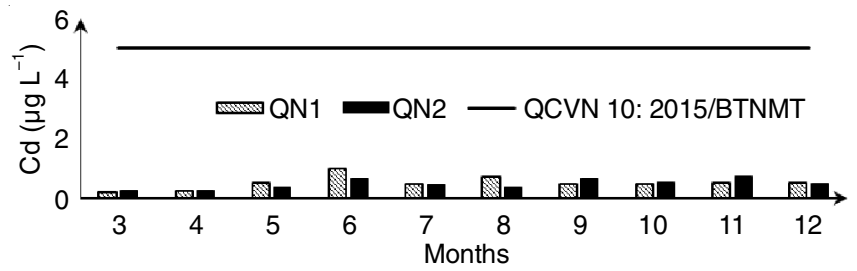

Fig. 1. Cadmium concentration $\left(\mu \mathrm{g} \mathrm{L}^{-1}\right)$ in seawater samples collected from Van Don coastal during 2015 
TABLE-3

CADMIUM CONCENTRATION $\left(\mathrm{mg} \mathrm{kg}^{-1}\right)$ IN SEDIMENT SAMPLES COLLECTED FROM VAN DON COASTAL DURING 2015

\begin{tabular}{cccccccccccc}
\hline \multirow{2}{*}{ Stations } & \multicolumn{10}{c}{ Months } \\
\cline { 2 - 13 } & 3 & 4 & 5 & 6 & 7 & 8 & 9 & 10 & 11 & 12 \\
\hline QN1 & 1.51 & 1.11 & 1.15 & 1.20 & 0.75 & 0.68 & 0.84 & 0.94 & 1.20 & 1.26 \\
QN2 & 0.96 & 0.85 & 0.78 & 0.68 & 0.73 & 0.79 & 0.68 & 0.87 & 0.80 & 0.84 \\
\hline
\end{tabular}

in the sediment samples and below permitted limits of QCVN 43:2012/BTNMT [8], the highest value recorded at the survey times were $1.51 \mathrm{mg} \mathrm{kg}^{-1}$ while the lowest value were $0.68 \mathrm{mg}$ $\mathrm{kg}^{-1}$. The average concentration of $\mathrm{Cd}$ were $0.98 \mathrm{mg} \mathrm{kg}^{-1}$. Unlike in seawater, the dry season cadmium in sediment acculated higher than in the rainy season. This mean that, the factor affecting the levels of cadmium in seawater and sediment were not similar. The coastal area, where the studied sediment samples were taken from, is very specific in terms of local oceanographic characteristic and due to fresh water influences. Besides, sediment samples differ in their origin in prevailing sediment type and organic matter content. According to study of Anh [9], the main particular composition in surface sediment in Bai Tu Long bay were sand, silt and silty- sand (80-91\%). Therefore, the adsorption of $\mathrm{Cd}^{2+}$ ion and other particular in sediment were strength. On the other hand, the dry season of Vietnam Northern (from November to April), temperature in marine water were slower than rainy season, this could increase bio-accumulation of cadmium in sediment in dry season (Fig. 2).

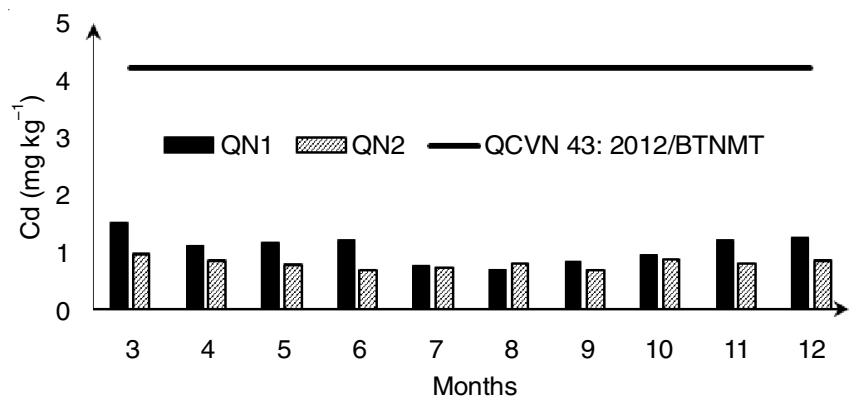

Fig. 2. Total cadmium concentration in sediment samples collected from Van Don coastal during 2015

The toxicity and bioavailability of heavy metals were not only related to their total contents, but also to their speciation, mobility capability and chemical interactions. The mechanism of heavy metal accumulation were shown by five fraction including: Exchange fraction (F1), bound to carbonates fraction (F2), bound to iron-manganese oxide franction (F3), oxidizable fraction (F4), residual fraction (F5). In the present study, cadmium fractions proportion in sediment in Van Don coastal in 2015 were following order: F5 > F3 > F4 > F2 > F1. Generally, the residual fraction were proportion (F5) highest, ranged from 29-67\%, small a part in the exchange fractions $(\mathrm{F} 1, \mathrm{~F} 2)$ that weak bound and could be absorbed by the biota directly, ranged from 4-19\% and 8-21\%, respectively. Therefore, the impact of cadmium speciation in sediment to organism in this area were not much (Fig. 3). However, based on the risk assessment code (RAC) scale, the sediments collected from the bivalves harvesting area in Van Don coastal could pose a medium risk for $\mathrm{Cd}$, indicated by $\mathrm{RAC}$ values ranging between 11 and $30 \%$ (Fig. 4).

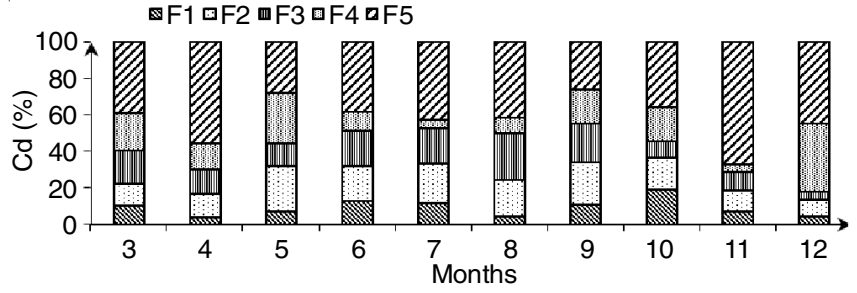

Fig. 3. Distribution of cadmium fraction in sediment were collected from Van Don coastal during 2015

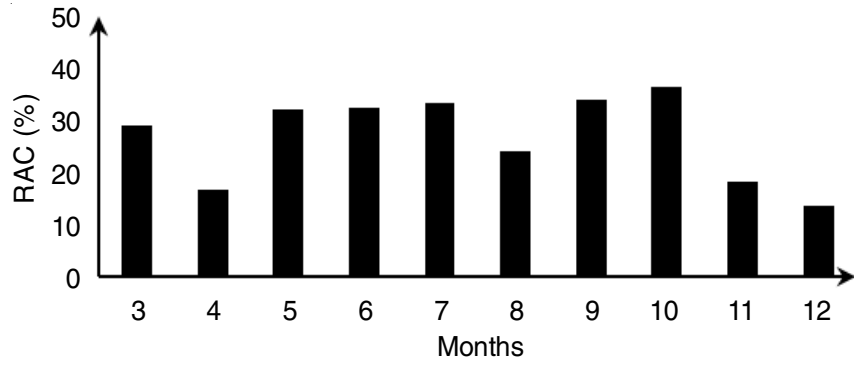

Fig. 4. Risk assessment code (RAC) for Cd in surface sediment from Van Don coastal during 2015

Cadmium accumulated in hakf-crenate ark (Anadara subcrenata), noble scallop (Mimachlamys nobilis) and undulating venus (Paphia undulata): Table-4 showed the concentration of cadmium in the whole tissue soft of three marine bivalve species include hakf-crenate ark (Anadara subcrenata), noble scallop (Mimachlamys nobilis) and undulating venus (Paphia undulata) collected from in the bivalves harvesting in Van Don coastal during dry season and rainy season in the 2015 . The analytical results have showed that cadmium concentration in noble scallop (Mimachlamys nobilis) were highest, range from $0.35-2.23 \mathrm{mg} \mathrm{kg}^{-1}$ wet weight while that in the undulating venus (Paphia undulata) and hakfcrenate ark (Anadara subcrenata) were lower, range from 0.25$0.81 \mathrm{mg} \mathrm{kg}^{-1}$ wet weight and $0.81-1.48 \mathrm{mg} \mathrm{kg}^{-1}$ wet weight, respectively. Comparing cadmium accumulations in three species at different depths in the survey station, results indicated that for most of the tissues studied, noble scallop (Mimachlamys nobilis) accumulated more pollutants than other two species that their habitat near the mainland. The values of undulating venus (Paphia undulata) were similar values measured by other researchers in Lake Timsal, Suez Canal, Egypt which ranged between $0.22-0.36 \mathrm{mg} \mathrm{kg}^{-1}[10]$ and $0.25-0.37 \mathrm{mg} \mathrm{kg}^{-1}$ wet

TABLE-4

CADMIUM CONCENTRATION $\left(\mathrm{mg} \mathrm{kg}^{-1}\right)$ IN THE WHOLE SOFT TISSUE OF THE BIVALVE SPECICES COLLECTED FROM VAN DON COASTAL AT DIFFERENT SEASONS DURING 2015

\begin{tabular}{lccc}
\hline \multicolumn{1}{c}{ Species } & Number & Rainy season & Dry season \\
\hline Mimachlamys nobilis & 60 & $1.589 \pm 0.497$ & $1.435 \pm 0.506$ \\
Paphia undulata & 60 & $0.420 \pm 0.151$ & $0.697 \pm 0.150$ \\
Anadara subcrenata & 60 & $1.043 \pm 0.629$ & $1.082 \pm 0.344$ \\
\hline
\end{tabular}




\begin{tabular}{|c|c|c|c|c|c|}
\hline \multicolumn{6}{|c|}{$\begin{array}{l}\text { TABLE-5 } \\
\text { CONCENTRATION OF CADMIUM }\left(\mathrm{mg} \mathrm{kg}^{-1}\right) \text { IN FOOT, STOMACH, GILLS, MANTEL AND ADDUCTOR } \\
\text { MUSCLE OF THE BIVALVE SPECIES COLLECTED FROM VAN DON COASTAL DURING } 2015\end{array}$} \\
\hline & Foot & Stomach & Gills & Mantel & Adductor muscle \\
\hline Paphia undulata & $0.28 \pm 0.11$ & $1.08 \pm 0.51$ & $0.47 \pm 0.09$ & $0.62 \pm 0.07$ & NA \\
\hline Anadara subcrenata & $0.51 \pm 0.22$ & $1.83 \pm 0,36$ & $0.96 \pm 0.47$ & $0.84 \pm 0.31$ & NA \\
\hline Mimachlamys nobilis & $0.54 \pm 0.21$ & $3.11 \pm 1.49$ & $0.87 \pm 0.39$ & $1.09 \pm 0.76$ & $0.06 \pm 0.02$ \\
\hline
\end{tabular}

weight in the Kuala Lumpur, Malaysia coastline [11] Cd levels measured in hakf-crenate ark (Anadara subcrenata) collected from Can Gio coastline in Ho Chi Minh City [12] ranged between $0.63-0.67 \mathrm{mg} \mathrm{kg}^{-1}$, values lower than the values measured in the present study. However, this still dependent to many causes including agencies structure, size and weight along with the age, seasonal factors and individual variability within the population. Generally, the concentration of cadmium throughout the study period remained below the WHO permissible limit of $2.0 \mathrm{mg} / \mathrm{kg}$ except in the noble scallop individual, cadmium concentration were still high (range above $2.0 \mathrm{mg}$ $\left.\mathrm{kg}^{-1}\right)$.

Table-5 showed the concentration of cadmium in foot, stomach, gills, matel and adductor muscle (applied for Noble scallop). It was highest in the stomach (digestive gland) and decreased in the order: stomach (digestive gland) $>$ mantel $>$ gills $>$ foot and adductor muscle. This could explain that in the digestive gland contain liver and kidneys this is an excretory organ, the food that were contaminated cadmium from environment through these organs and uptake in their bivalve's body. The uptake of cadmium relate to the ability of the metal to penetrate the membrane of the cells in the tissues and then be kept retained at these organs.

\section{Conclusion}

This is the first study to reveal cadmium and their speciations in seawater, sediment and soft tissue of bivalves in Van Don coastal, Quang Ninh, Vietnam. The analytical results showed that cadmium concentration in seawater and sediment were slow and below the QCVN 2015/BTNMT permissible limits. In three bivalves species that were studied cadmium accumulation, noble scallop (Mimachlamys nobilis) accumulated highest, followed by hakf-crenate ark (Anadara subcrenata) and undulating venus (Paphia undulata). Generally, the concentration of cadmium throughout the study period remained below the WHO permissible limit of $2.0 \mathrm{mg} / \mathrm{kg}$. Cadmium levels in tissue were in the order of stomach $>$ mantel $>$ gill $>$ foot and adductor muscle.

\section{ACKNOWLEDGEMENTS}

The authors acknowledged the assistance of staffs from the Laboratory of Physical Chemistry and Analysis, Research Institute for Marine Fisheris throughout the research work.

\section{REFERENCES}

1. APHA, Standard Methods for the Examination of Water and Wastewater, American Public Health Association, American Water Works Association and Water Pollution Control Federation: Washington, edn 19, pp. 397-404 (1995).

2. UNEP/IOC/IAEA, Determination of Total Cadmium in Estuarine Waters and Suspended Matter (1982).

3. FAO, FAO Fish. Tech. Pap., 158, 124 (1976).

4. A. Tessier, P.G.C. Campbell and M. Bisson, Anal. Chem., 51, 844 (1979); https://doi.org/10.1021/ac50043a017.

5. Ministry of Natural Resources and Environment of Vietnam, National Technical Regulation on Marine Quality in Vietnam, Decision 67/2015/ QD-BTNMT 21/12 (2015).

6. D.J. Balgan Anand and S.M. Jelastin Kala, Int. Res. J. Environ. Sci., 4, $22(2015)$.

7. N.C. Hoi and L.V. Dieu Water Environmental Quality of Ha Long Bay, Vietnam, International Development Research Center Ottawa, Canada pp. 68-71 (1995).

8. Ministry of Natural Resources and Environment of Vietnam, National Technical Regulation on Sediment Quality in Vietnam, Decision 10/2012/ TT-BTNMT 12/10 (2012)

9. N.N. Anh, Ph.D. Thesis, The Surface Sediment Characteristics and Evolutionary Dynamics in Hai PhongQuang Ninh Coastal, Department of Geological Department, Ha Noi University of Science Hanoi, Vietnam (2014).

10. K. El-Moselhy and M.H. Yassein, Egypt. J. Aquat. Res., 31, 13 (2005).

11. I. Mat, Bull. Environ. Contam. Toxicol., 52, 833 (1994); https://doi.org/10.1007/BF00200691.

12. T.K.P. Nguyen and N.C. Khoa, Asian J. Chem., 25, 8552 (2013); https://doi.org/10.14233/ajchem.2013.14838. 